\title{
Science, stories and scholars
}

\section{BOOK TITLE:}

The White Lady and Atlantis, Ophir and Great Zimbabwe:

Investigation of an

archaeological myth

\section{BOOK COVER:}

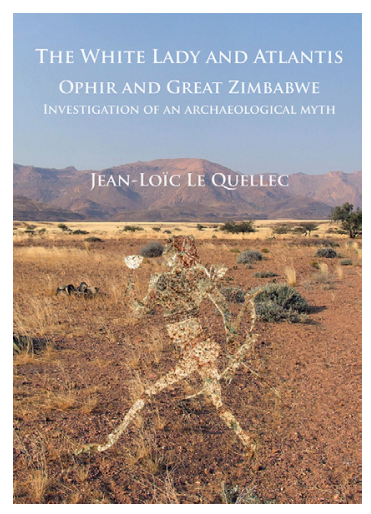

AUTHOR:

Jean-Löic Le Quellec

ISBN:

9781784914707 (softcover)

\section{PUBLISHER:}

Archaeopress, Oxford; GBP45

\section{PUBLISHED:}

2016

\section{REVIEWER:}

Anne Solomon

\section{AFFILIATION:}

Independent Researcher, Vale of Glamorgan, Wales, United Kingdom

\section{EMAIL:}

solomon.annec@gmail.com

\section{HOW TO CITE:}

Solomon A. Science, stories and scholars. S Afr J Sci. 2017:113(11/12), Art. \#a0239, 1 page. http://dx.doi. org/10.17159/sajs.2017/a0239

(c) 2017. The Author(s). Published under a Creative Commons Attribution Licence.
Scientific discoveries have always inspired writers and permeated popular culture, most obviously in science fiction. Sci-fi's precursor was the 'scientific romance' - a booming 19th and early 20th century genre. In this volume, Jean-Löic Le Quellec, a French archaeologist and specialist in Saharan rock art, examines this sub-genre, as exemplified by Conan Doyle's 1912 novel The Lost World, but prefigured by 'lost race', rather than 'Iost world', narratives such as Rider Haggard's King Solomon's Mines (1885) and She (1886). Rather than considering the impact of how science meets stories, Le Quellec considers its inverse: 'The blurring of frontiers between science and literature, in which novelists discuss scientific questions and scholars tell stories' (p. 173). The book is profusely illustrated in colour and black and white. A small quibble is that the figures are not numbered; another is the absence of an index. However, these do not detract from the overall value of the work.

The study's starting point is the Namibian rock painting dubbed the 'White Lady of the Brandberg' that became famous after the abbé Henri Breuil (1877-1961) published a book of the same name in 1955. ${ }^{1}$ Breuil, a French priest and archaeologist, was known as the 'father of prehistory' by his fans and the 'pope of prehistory' by his critics. After valuable work on European Palaeolithic cave art, Breuil worked for a decade in South Africa at the invitation of Jan Smuts. The 'White Lady' (which is neither white nor female) was 'discovered' in 1918 by Reinhard Maack, a German geologist, but attracted little attention until Breuil published his ideas (Chapter 1).,2 They were, in essence, that the 'lady' and other figures represented foreigners of Mediterranean (perhaps Cretan) or Egyptian origin.2(p.11) The subtext was the racist notion that indigenous peoples could not have produced such works - a prominent theme also in initial 'scientific' investigations of Great Zimbabwe (Chapter 5). As it turned out, much of Breuil's 'White Lady' interpretation was the work of his assistant, Mary Boyle, whose thinking plainly drew heavily on 'lost world' narrative themes (Chapter 3).

Le Quellec meticulously documents the surprising size and reach of this genre, discussing many of perhaps a thousand such tales, in English and French literature, Afrikaner culture and film (Chapters 8, 11, 13). The remarkably uniform themes and motifs of these stories are familiar. They feature pockets of surviving ancient peoples - Phoenicians, Egyptians, Sabaeans, Hamites, Assyrians and Romans, to name a few - encountered by intrepid European explorers in Africa or other wild places; powerful white African queens, hideous cannibals and other clichés. Le Quellec then draws out connections between the archaeological interpretations of Breuil and others (in rock art, notably Frobenius and, in the Sahara, Henri Lhote) and these dashing adventure stories. Often written as if accounts of real expeditions and experiences, some even included photos to enhance the illusion of factuality. Also discussed in some detail are the prominent motifs of lost civilisations, many with fabulous stores of gold and treasure. Ophir turns up in Great Zimbabwe and West Africa (Chapter 10), Atlantis is found in the Sahara desert (Chapter 6), while bull-jumpers from Knossos and Phoenician ships appear in African rock art.

The irony, Le Quellec suggests, is that Breuil's reading of the Namibian images arose just as the 'lost world' genre, which clearly ran in parallel with colonial ambitions and expansions, was coming to an end. Moreover, prehistorians, such as Randall-Maclver and Caton-Thompson at Great Zimbabwe, and some South African archaeologists, had persistently debunked the notion of such foreign influence in African prehistory, from 1905 onward; yet the popular appeal of these myths endured - and lingers even today.

Although the analysis of the ways in which literature dealing with Africa served colonial agendas is not new, and the work engages rather lightly with racialised, colonial era science, these are not the author's foremost concerns. The volume is an invaluably detailed overview that extends critical scrutiny beyond southern Africa and anglophone literary and research traditions. The detailed dissection of the myth of the White Lady painting is an important contribution, of relevance beyond rock art research itself. It reveals too the machinations of power in academic circles. Although some were brave enough to challenge Breuil, others were loath to cross this powerful academic figure. Even taking account of Breuil's advanced age at this point (in his seventies when he published his 'White Lady' volume), he comes across as self-aggrandising and blinkered by self-confidence; happy both to help himself to others' work, in particular that of his devoted (if deluded) assistant, Mary Boyle, and to trivialise his predecessors' contributions. Le Quellec notes Breuil's disdain for earlier recorders of the Brandberg site, although the accuracy of his own methods was hardly better. Breuil eschewed photography in favour of tracings; he blithely documented how his team would wet the paintings to enhance their visibility, outline faint images with charcoal (thus contaminating them for any future radiocarbon dating) and then 'trace' them on paper that was barely transparent (Chapter 12).

With hindsight it is easy to spot the mind-blowing absurdity of these researchers' methods and their claims to scientific factuality that Le Quellec diligently analyses, but the study has ongoing relevance as a cautionary tale for rock art and other researchers. Le Quellec poses the question: given the permeability of scientific research and popular culture, could such scientific mythopoiesis be possible today? This may be a reference to the allegedly scientific status of shamanistic readings of rock art, which have been deeply controversial, and have similarly been analysed in relation to a crossover with popular culture, namely new age spiritualities. ${ }^{3}$

In sum, the book is a highly informative contribution to knowledge and an accessible read for anyone interested in rock art, African history, literature or the history and sociology of knowledge. As a bonus, there are not many academic books that can regularly make the reader laugh out loud.

\section{References}

1. Breuil H (with Mary E. Boyle and E.R. Scherz). The White Lady of the Brandberg. London: Faber and Faber; 1955.

2. Breuil H. The White Lady of Brandberg, South-West Africa, her companions and her guards. S Afr Archaeol Bull. 1948;3(9):211. https://doi.org/10.2307/3886881

3. Kehoe AB. Shamans and religion: An anthropological exploration in critical thinking. Long Grove, IL: Waveland Press; 2000. 